\title{
資源の追加と削減に基づく並列分散最適化法の収束性の改善*
}

\author{
三 木 光 範*1, 廣 安知 之*1, 池田大 樹*2
}

\section{Improvement of the Convergence in the Distributed Optimization by Resource Addition and Reduction Method}

\author{
Mitsunori MIKI, Tomoyuki HIROYASU*3 and Taiju IKEDA
}

${ }^{* 3}$ Department of Knowledge Engineering, Doshisha University,

1-3 Tatara, Miyakodani, Kyo-Tanabe-shi, Kyoto, 610-0321 Japan

\begin{abstract}
The distributed optimization method by resource addition and reduction, which is called the DORAR method, is a new optimization method for the minimization of the total resource of systems, and it has been found to be suitable for parallel processing and very robust for initial solutions. The only parameter in the method is the amount of the small additional resource used for increasing the resources of the elements of a system. It has been found that the amount of the additional resource can be determined from the required accuracy of final results. However, the problem on slow convergence still remains. This paper introduces three improvements for adjusting the additional resource aiming its fast convergence and the high accuracy of the converged solutions. One is the gradual reduction of the additional resource, one is the utilization of the sensitivity information, and one is the adaptation of the additional resource using the history of the resource reduction. These improvements are tested for optimizing truss structures and their effectiveness is examined.
\end{abstract}

Key Words : Optimum Design, Distributed Algorithm, Parallel Optimization, DORAR Method

\section{1.はじめに}

近年，並列計算機の発達に伴い，最適化アルゴリズム を並列化する試みが行われているい。しかしながら，従 来の最適化手法は本質的に逐次処理の部分を多く含み, 並列化は容易ではない。このため, 新しい並列最適化 のアルゴリズムを考える場合には，自律分散の概念2) が有効であると思われる。自律分散システムとは，シ ステム全体がそれより規模の小さいサブシステムから 棈成され，それぞれのサブシステムはシステム全体が うまく機能するように自律して挙動するシステムであ る.

前報3).4では，このような自律分散の概念に基つく並

*原稿受付 2000 年 11 月 22 日.

*1 正员，同志社大学工学部( 6 610-0321 京田辺市多々羅都谷 1-3).

*2 同志社大学大学院.

E-mail : mmiki@mail.doshisha.ac.jp
列分散最適化アルゴリズムである資源追加削減法 (Distributed Optimization by Resource Addition and Reduction Method, 以下 DORAR 法と略記する) を提案した。またアアルゴリズムの正当性の数学的検 証も行った5). DORAR 法は，局所ルールに基づく最適 設計のための新たなアルゴリズムであり，資源最小化 問題に定式化できる連続変数の非線形最適化問題を並 列計算譏で解くために開発された。この方法には，複 数の制約条件を容易に扱える，および任意の初期值か ら収束するロバスト性を有するといった特徴がある。 しかしながら、設計点を制約条件に近づける処理を反 復することで最適化を達成するというアルゴリズムの 原理上，収束まで計算の繰り返しを要するという問題 点があり，その改善のための研究は行われていない。 本論文では，収束性の向上およびより厥落な最適解を 得るためのいくつかの手法の提桇を行う。そして，提 
案した手法の有効性を離散システム最適化問題に適用 することで検討する。

\section{2. 資源の追加と削減に基づく 分散最適化法}

\section{1 資源追加削減法（DORAR 法）の概略 ここで}

は，離散的な要素を有するシステムの最適化問題を考 える.目的は，システム全体として必要な翼源の最小 化であり，それは各要素の資源の和で表される。シス テムには要求される機能が種々の制約条件として課せ られている。それらは複数の全体制約条件と複数の局 所制約条件である。すなわち，式(1)のように定式化で きる資源最小化問題を考える。

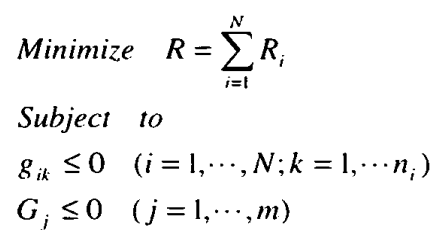

ここで， $R$ はシステムの全資源， $R_{i}$ は要素 $j$ の資源, $N$ は要素数, $g_{i k}$ は要素 $i の k$ 番目の局所制約, $G_{j}$ は $j$ 番目の全体制約である。

DORAR 法のアルゴリズムは，次の手順で示される。

1）各要素は局所制約条件を基にその資源余裕を評価 L，局所資源余裕とする。

2）各要素は全体制約条件を基にその資源余裕を評洒 し，それらに責任係数を乗じたものをその要素の全体 資源余裕とする。珼任係数は感度情報を交換しない場 合には，一定値（要素数の逆数）とするのが妥当であ 万.

3）手順 1),2）の資源余裕の最小値を各要素の臨界資源 余裕とし，それを削減する。この処理を資源削減処理 と呼ぶ。

4）各装秦に一定の微少な資源（以下， $\Delta R$ と略記する) を追加する。この処理を資源追加処理と呼ぶ。

5）乎順 1)から 4)を繰り返すことにより最適解を得る： DORAR 法のアルゴリズムの詳細は，前報3を参照さ れたい.

2.2 DORAR 法の特徵と問題点 . 離散システムの最 適設計閣題を分散的に解くための方法として提案され たDORAR 法の特徵は次のようなものである。
- 自律分散の概念に基づく並列処理に適した分散最 適化アルゴリズムである。

-人為的に取り扱うパラメータは $\Delta R$ のみであり，そ の設定は比較的容易である。

-システムに課せられた複数の制約条件を扱うこと ができる。

- 任意の初期值からも収束し, 鼠適解を得ることがで きる。

これまで DORAR 洼は, 電気回路および離散構造物最 適設計問題に適用され，その有效性が検証されている 3).4).5)。しかしながら，アルゴリズムの収束性や最適解 の精度に関する研究は行われていない。本論文では, 収束性や最適解の精度の改善を目的とした種々のアル ゴリズムの提案を行う。

\section{3. カ学的離散システムへの適用}

3.1 最適化の対象最適化の対象として図 1 に示 す離散的要素から成る 8 節点 15 部材のトラス構造の最 小体積設計問題を考える。使用材料は䉍単のため，絴 弾性係数 10GPa の線形弾性体とする．目的は体積の最 小化であり，したがって，DORAR 法における資源はこ こでは各部材の体積となる。この閣題は闹一材料の場 合には構造の重量を最小にする問題と等価である。制 約条件は，局所制約条件として部材の引張，圧縮応力 および座屈強度を考え，全体制約条件として一つの節 点変位を考える。

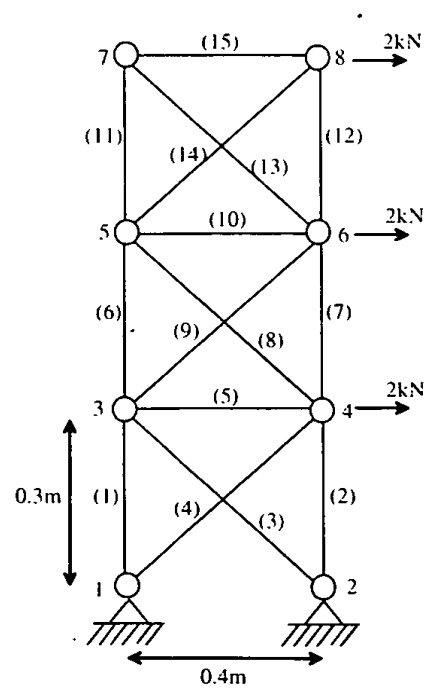

$\mathrm{i}$ :node index; (i):member index

Fig. 1 A 15 -member truss structure 
部材は中夷叫形断面とし、設計变数は部材の体積であ る.負獄荷重は図 1 に示すとおり，節点 4,6 および 8 にそれぞれ $2 \mathrm{kN}$ ずつ水平荷重を負荷した。応力制約に おける限界值を引張 $40 \mathrm{MPa}$ ，变位制的として節点 8 の 変位を $0.006 \mathrm{~m}$ 以下とした。

乱数を用いて 8 節点 15 部材トラス構造物の各部材の 円形断面の半径を与えた初期值を 5 種類設定した。 そ れらの初期值の断面積分布を図 2 に示す。初期値にお ける全体の体積は最小 $1.43 \times 10^{-2} \mathrm{~m}^{3}$, 最大 $2.76 \times 10^{-2} \mathrm{~m}^{3}$ で あった。

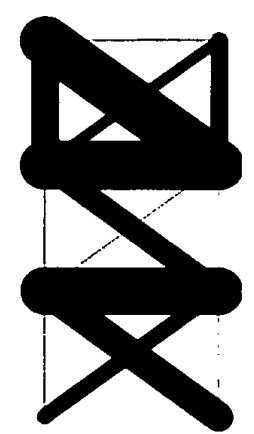

Initial config. 1

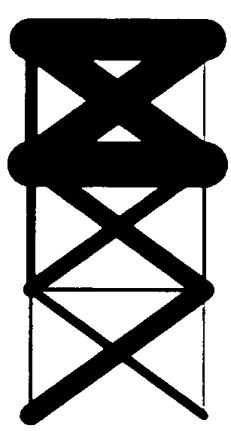

Initial config. 2

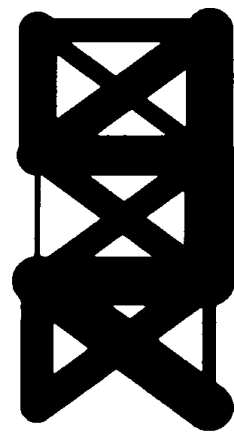

Initial config. 3

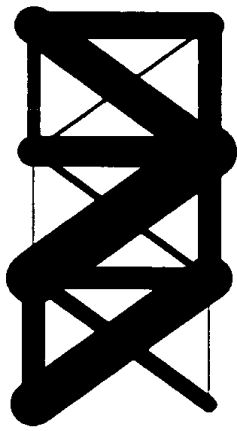

Initial config. 4

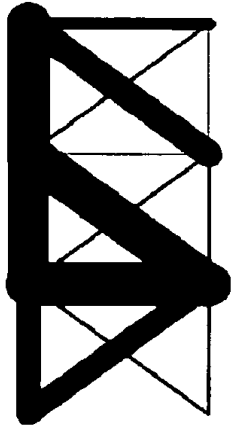

Initial config. 5
Fig. 2 Initial distributions of the sectional areas of the members

3.2 最適化の結果図 2 に示した 5 種類の初期值 を対象として，最適化を行った。資源追加処理におけ る $\Delta R$ の大きさは, その時点でのシステムの全資源量, すなわちトラスの全体積の $0.1 \%$ よび $0.01 \%$ 一定值 とした。よって，資源追加処理によって 1 ステップご とに, 15 部材トラス構造物全体にそれぞれ $1.5 \%, 0.15 \%$ の資源が付加されることになる。著しい相違を持つ初 期值から最適化を行ったにもかかわらず，全て発散せ ず，良好な収束過程を示した。得られた最適解は 2 種 類であった。それらの解の断面積分布を図 3 に示す。
初期値 4 のみが解 Bに収束し，それ以外は解 Aに收束 した。解Aは大域的最適解であると考えられる。

ここでは, DORAR 法に扔ける唯一のパラメータであ る $\Delta R$ が収束に及ほす影讳を検証する。代表的な例とし て，初期值 1 および初期值 2 に関する 10000 ステップ までの資源履歴を図 4 および図 5 に示す。全体積は計 算の初期段階で急速に減少し，そののち緩慢な变化過 程に入ることがわかる。図 4 および図 5 より， $\Delta R$ の 大きさは，収束性や最適解の精度に多大な影隌を及ほ すものであることがわかる。すなわち， $\Delta R$ が大きけれ ば収束性は向上するが,解の精度は低くなる。一方， $\Delta R$ を小さくすれば収束は遅れるが，解の精度の问上を実 現できる，次節では，収束性の向上と最適解の精度向 上の両者をめざした方法を提案する。

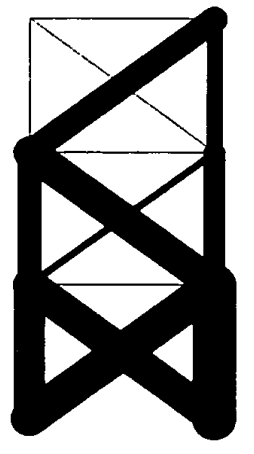

Solution A

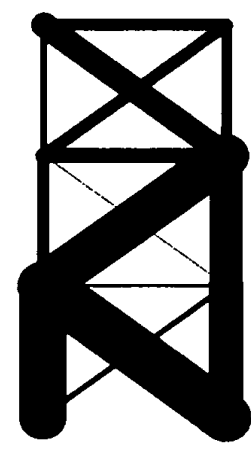

Solution B
Fig. 3 Converged solutions

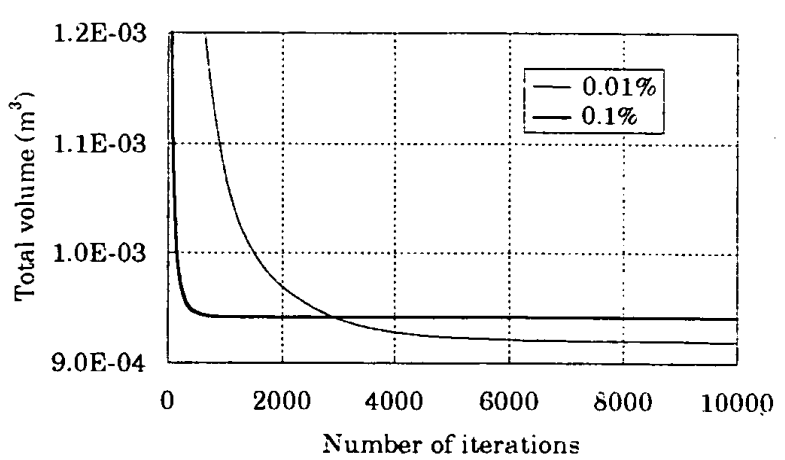

Fig. Histories of the total volume from initial config. 1 with constant $\Delta R$ 


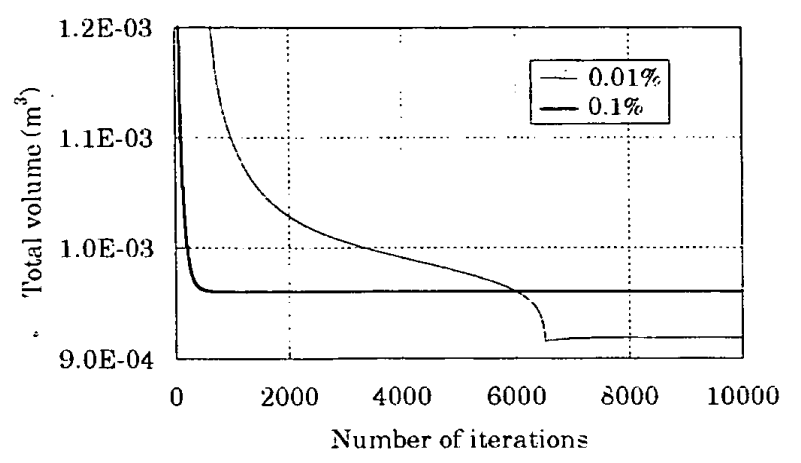

Fig. 5 Histories of the total volume

from initial config. 2 with constant $\Delta R$

\section{4. 収束性および最適解の精度 を向上させる方法}

4.1 追加資源の低減処理の提案とその有効性の検証 前章では, 追加資源 $\Delta R$ の大きさが収束性や最適解の精 度に多大な影響を及ぼすことを検証した。そこで， $\Delta R$ の初期值を大きく設定し，その後，段階的に低減させ る処理を提案する。これにより, 収束性, 最適解の精 度の両者の向上が期待できる、 $\Delta R$ の初期値は全資源量 の $0.1 \%$ とし，システムの総資源量の変化が緩慢になっ たとき，すなわち棇資源量の変化率が一定值以下（経 験的に $1.0 \mathrm{e}-04$ に設定）となったときに $1 / 10 に$ に低減さ せるものとした。

図 2 に示す 5 種類の初期值から, 提案する $\Delta R$ の段階 的な低減処理を適用して最適化を行うことで，提案の 有効性を検証する。代表的な例として，初期值 1 抢よ び初期值 2 の 750 ステップまでの瓷源履歴をそれぞれ 図 6 および図 7 に示す。

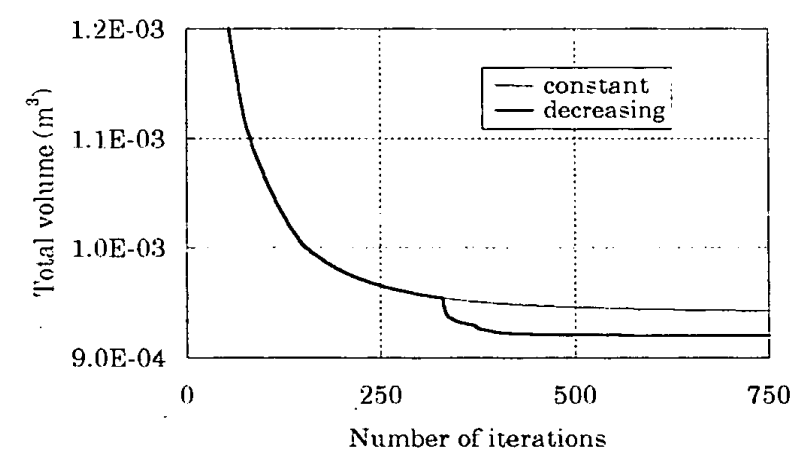

Fig. 6 Histories of the total volume from initial config. 1

with constant $\Delta R$ and with decreasing $\Delta R$

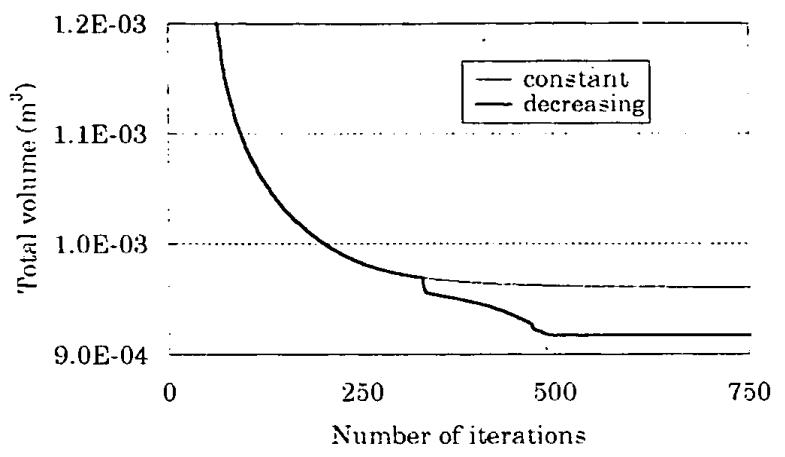

Fig. 7 Histories of the total volume from initial config. 2

with constant $\Delta R$ and with decreasing $\Delta R$

図 4 と図 6, 図 5 と図 7 をそれぞれ比較すると， $\Delta R$ を 0.01\%の一定值としたときの 10000 ステップにおけ る最適解の精度を， $\Delta R$ の段階的な低減処理を用いると 500 ステップ程度の繰り返し計算で実現できることが わかる、よって， $\Delta R$ を段階的に低減させる処理は, 収 束性の改善および解の精度向上の雨者を実現するため には極めて有効であることがわかった。

\section{2 感度情報の交換による貫任係数の適応的変化}

4.2.1 責任係数の適応的変化 DORAR 法では， 課せられた制的条件の分類を行う。この分類により， 各要素は自律分散的に挙動することが可能となる。制 約条件については，システムを構成する各要素が単独 で資源を変化させた結果，満たすことのできるものを 局所制約条件と定義し，それ以外を全体制約条件とす る。全体制約条件はシステム全体に課せられた制的で， そのシステムを構成する要素全体で満たされるべき制 約であると考えられる。そのため, 姴素は全体制約条 件に対する資源余裕に对しては，責任係数を乗じ，こ れを改めて資源余裕とする。責任係数とは，全体制約 条件を達成するためのシステム内における要素の責任 の重さ，すなわち，システムにおけるその要素の重要 度を示すものであると考えられる．従来の DORAR 注 では，要素間の情報交換の頻度を減らすため，要素間 の重要度は一定と考之, 責任係数は要素数の逆数とし ていた。

本節では, 各要素の全体制約条件に関する感度をその 要素の重要度を示す情報とし，それを要素間で交換す ることで，システムの状態に応じて最適な責任係数を 与えることを目標とするアルゴリズムの提案を行う. 要素間で交換する情報は全体制約に関する感度のみで 
あり，各要素の局所制䄪に関する感度は交換しない。 感度情報を朋いると，各刑秦の济源を微少量変化させ たときのシステムの谷签を推定することが可能である。 この手法は，要素が利用する情報量を增加させるため， 収束の加速が期待できるが，システムを構成する全て の要素の感度情報を必要とするため，姴素間における 情報交換の頻度が増加するという問題点がある。

要素の全体制約に関する感度情報から責任係数を決 定するための基本的な考えは，制的条件に対する感度

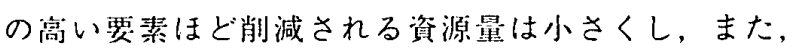
感度の低い要素ほど削減される資源量を大きくすると いうものである。

要素 $j$ の $j$ 番目の全体制䄪 $G_{j}$ に関する感度 $S_{i j}$ は式 $(2)$ のように表すこととする。感度解析した結果，各要素 の状態が制的を満たす方向に遷移すると考えられる場 合，感度 $S_{i j}$ は負となる。

$$
S_{i j}=\frac{\partial G_{j}}{\partial R_{i}}
$$

ここではまず，システムの状態が制約条件を満たして いる場合を考える，この場合では，設計解が可能領域 内にあることから，資源削減処理において各要素の資 源は削減される。感度 $S_{i j}$ が負のときは, 要素 $i$ の費任 係数 $\alpha_{i j}$ は式(3)のように感度の逆数に比例した値とす る.これは, 重要度の高い要素の資源の削減量は, 他 の要素と比較して相対的に小さくするという考えに基 づくものである. 感度 $S_{i j}$ が正のときは, その要素の資 源は制約を満たすためには不要であると考えられ，そ の要素は全ての資源を削減される。

$$
\alpha_{i j}=\frac{S_{i j}^{-1}}{\sum_{i=1}^{N} \min \left(0, S_{i j}^{-1}\right)} \quad\left(S_{i j} \leq 0\right)
$$

次に, システムの状態が制約条件を満たしていない場 合を考える。この場合では，可能領域外にある設計解 を制約内に移動させる必要があり，資源削減処理にお いて各要素の凅源は追加されることになる。感度 $S_{i j}$ は 負のとき，䐝任係数 $\alpha_{i j}$ は式(4)のように感度に比例した 值とする。これは, 重要度の高い要素の資源の追加量 は，他の要素と比較して相対的に大きくするという考 えに基づくものである. 感度 $S_{i j}$ が正のときは，その要
素の资源は制的を满たすための重要涭が低いと考えら れ, 资源削減は行わない。

$$
\alpha_{i j}=\frac{S_{i j}}{\sum_{i=1}^{N} \min \left(0, S_{i i}\right)} \quad\left(S_{i j} \leq 0\right)
$$

次に，感度情報の交換による責任係数の適応的变化を 、用いた設計点の移動を検討する。図 8 は，2 要素の場合 において，費任係数を要素数の逆数 $(=1 / 2)$ の…定值 とした場合および珼任係数の適応的変化を用い最適化 を行った場合の資源平面での設計点の移動過程を表し ている。ここで, 現在の設計点はP $P_{i}$ 表されている，観 測される有効制約条件は全体制約条件のみとする。

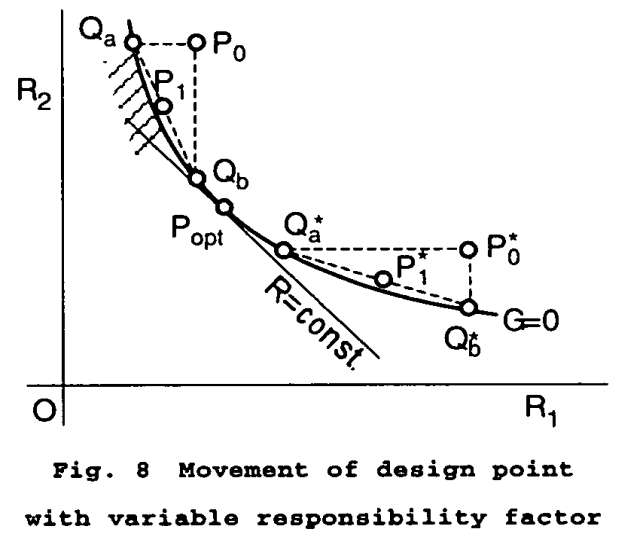

責任係数がー定值の場合, 要素 1 の全体資源余裕は 線分 P0-Qa で表され, 責任係数 $1 / 2$ を乗じた臨界資源 余裕はこの長さの半分となる。一方, 要素 2 の全体資 源余裕は線分 P0-Qb で表され，責任係数 $1 / 2$ を乗じた 臨界資源余裕はこの長さの半分となる。これらの臨界 資源余裕を削減すると, 設計点は線分 $\mathrm{Qa} \cdot \mathrm{Qb}$ の中点 であるP1に移動する。

次に，責任倸数の適応的変化を用いた場合を考え る. 設計点 $\mathrm{P} 0$ 付近で考えると, 線分 $\mathrm{P} 0-\mathrm{Qb}$ で表され る要素 2 の全体資源余裕は, 線分 PO-Qa で表される要 素 1 の全体資源余裕より大きく，このため制約条件 $\mathbf{G}$ に対する資源量の感度が設計点 P0 付近で大きな变化 がないと仮定すると，式(3)より要素 2 の貫任係数 $\alpha 2$ は要素 1 の賷任係数 $\alpha 2$ より小さくなる. 臨界資源余 裕は各資源余裕にこれらの責任係数を乗じて計算さ れるため，要素1の臨界資源余裕は貴任係数が $1 / 2$ の ときと比べて小さくなる。一方, 要装 2 の臨界資源余 裕は責任係数が $1 / 2$ のとと比べて大きくなる。この 
ため,これらの臨界資源余裕を削減すると設計点はP1 より $\mathrm{Qb} に$ に近くなる。このような状海が生じる場合, 最適点Popt は必ず Qb 側に存在する。このため, 費任 係数の適応的変化を用いた場合の資源削減に基づく 設計点の移動は，責任係数を固定した場合と比較して， より最適設計点に近づくことが分かる。

これとは逆に，設計点 $\mathrm{P} 0$ *付近では最適設計点は $\mathrm{Qa}$ *側に存在するが，このときは設計点 $\mathrm{P} 0$ *では制䄪条 件の要素 1 の資源に対する感度の力が要素 2 に対する。 感度より小さくなり, 設計点は $\mathrm{P} 1$ ×より $\mathrm{Qa}$ *側に移動 する.こうして，責任係数の適応的変化を用いた場合 には，設計点の移動は責任係数が一定值の場合に比べ て加速されることになる。

4.2.2 責任係数の適応的変化の有効性の検証 ここでは，感度情報の交換による責任係数の適応的変 化の有効性を検討する。追加資源 $\Delta R$ は全資源量の $0.1 \%$ 一定値とし, 提案の有効性を確認するため, $\Delta R$ の低減処理は行わない。責任係数を要素数の逆数の一. 定值，提案した責任係数の適心的変化を用い最適化を 行ったときの 500 ステップまでの資源履歴をそれぞれ 図 9 および図 10 に示す。初期値 5 のみが責任係数を变 化させると収束性が向上した。しかしながら，初期值 2 および初期值 3 については責任係数を変化させると, 蛽任係数を要素数の逆数の一定值としたときと比較し て40ステップ付近から収束が遅れることがわかった。 この原因を検証するために，初期值 2 の 40 ステップ 後の図 9 および図 10 における断面積分布を唡証した。 図 9 では責任係数は一定值（感度情報は使用していな い）であり，図 10 では感度情報に基づく責任係数の適 伈的変化を用いている。 それぞれの 40 ステップ後の断 面積分布を図 11 に示す。これらの 2 種類の断面積分布 から，40 ステップ瑷の収束解は異なった形状で負荷荷 重を支持していることがわかる。すなわち，責任係数 の適応的变化を用い最適化を行った 40 ステップ彴の収 束解は, 図 3 に示す解 B と極めて類似した形状で負荷 荷重を支持していることがわかる。そのため，40ステ ップ以降の最適化に関しても，それらの部材が重要視 される結果, 大域的最適解への収束が荤れると考える ことができる。また，責任係数を一定值とした収束解 は，責任係数を変化させて得られた収束解と比較して 総資源量は大きいものの，部材の断面積分布に大きな 偏りはないことから，設計空間において解 B との距離 が遠い経路で最適化が行われたと考えることができる.

また，初期値 3 についても 40 ステップ後の断面皘分布 を比較した結果，初期値 2 と同様のことがわかった。

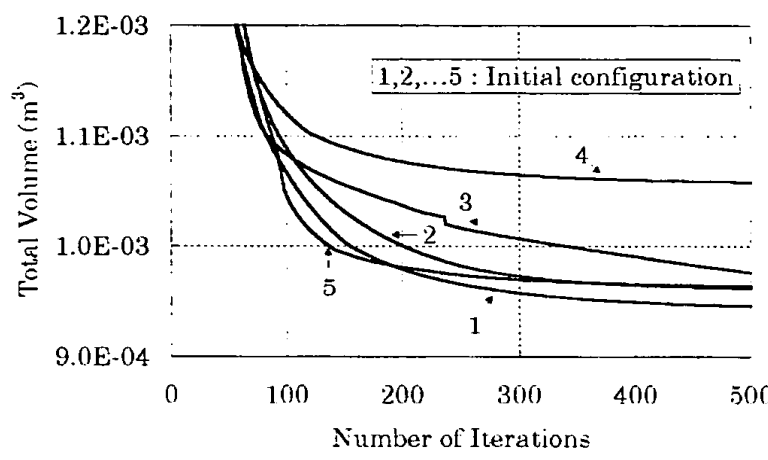

Fig. 9 Histories of the total volumes with constant responsibility factor

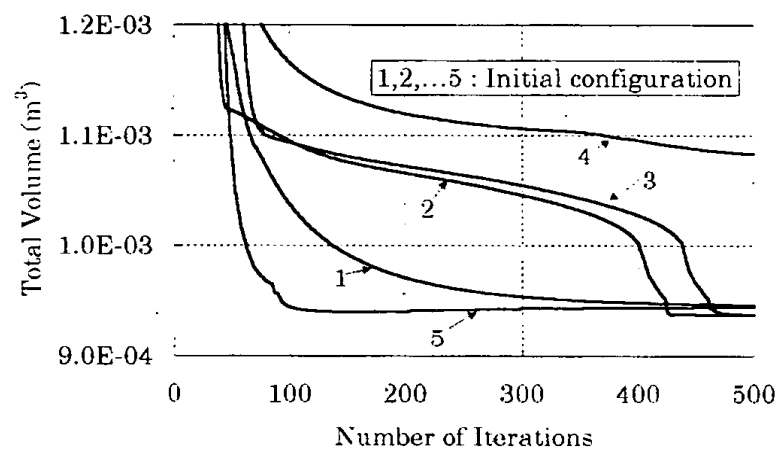

Fig. 10 Histories of the total volumes with variable responsibility factor

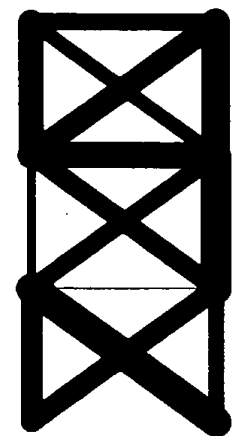

With constant responsibility factor

Fig. 11 Intermediate
次に,40 ステップ以前は各要素の責任係数を要素数 の逆数の一定值とし, 計算の繰り返しがある程度進行 した 40 ステップ以降に責任係数の変化を用いて最適化 を行った.500ステップまでの資源履歴を図 12 に示す. 
初期值から英任係数の適匛的变化を行うと初期解依存 が生じて収束が韭札た初期値 2 および初期値 3 に対し ても，収束性が问上することが確認できる。

以上のことから，最適化の計算過程で部材の断面積分 布が解 B と類似した断面皘分布となった場合，初期値 から琵任係数の適応的変化を行うと，初期解依存が生 じ，収束が遅れることがあると考えられる。よって， 計算がある程度進行してから，青任係数の適応的变化 を行うことは，初期解依存をなくすために有効である といえる.

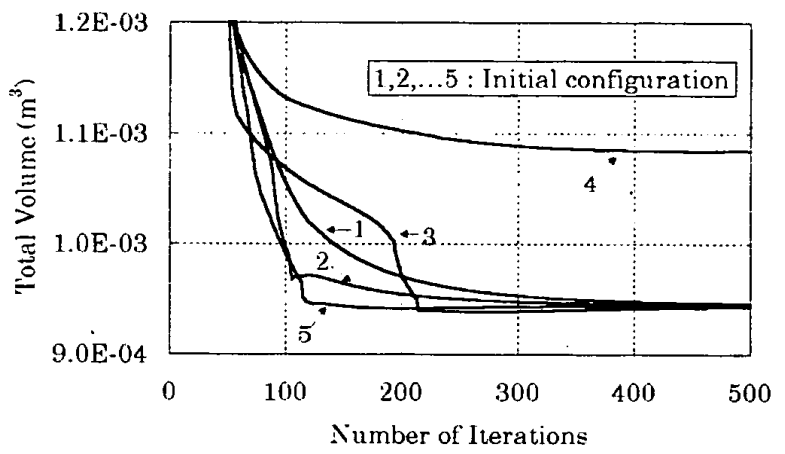

Fig. 12 Histories of the total volumes with constant and variable responsibility factors

\section{3 要素の自律的な加速アルゴリズム}

\subsection{1 収束加速アルゴリズムの提案ＤORAR 法} では資源余裕の見積もり，資源削減および資源追加の 繰り返しでシステムの最適化が達成される。そのため， 設計点が最適解と同じ有効制約に近づくと，最適解を 得るまで多くの繰り返し計算を必要とする。その繰り 返し計算においては，システムを構成する各要素の資 源は規則的かつ単調に変化しているものと思われる. よって，各要素がその変化を把握し，それに基づき自 律的に資源を変化させることができれば，収束の高速 化が奏現できると考えられる。

本節では，収束性の向上を目的として，要素が自己の 資源を自律的に変化させ，収束を加速するためのアル ゴリズムを提案する。それは，各要素が自己の資源の 変化を常に記憶し，その変化が緩慢になるとそれを判 断し，大きく資源を変化させる処理である。ここで提 案する自律分散的な加速処理を, 離散的な各要素が行 った結果, システム全体としての最適な状態への収束 性の向上が期待できる。

各要素の収束加速アルゴリズムにおいて重要なこと
は，次の二つである。第一に，加速アルゴリズムはシ ステムの全体情報を必要とせず，各琴紮が完全に日律 的に挙動できなければならない，第二に，加速县を光 の時点での要瑟の状態に応じて適応的に決定する必要 がある。そのために，加速処理ごとにその有効性を確 認する必姴がある。

取束加速アルゴリズムは，次の手順で示される。

1）各要素は自己の瓷源の履歴を保持する。すなわち, 常に過去の一定ステップにこでは経験的に5ステッ プに設定）の資源量を記憶する.

2）設定した一定ステップごとに，保持している資源の 履歴を検証する。そこで，資源の变化が緩慢と判断さ れた場合（ステップごとの瓷源の变化率が一定值以 下）は，加速処理を適用する。加速量は自己の前ステ ップにおける資源量の変化に基づいて決定し，加速量 の初期值を前ステップの资源変化量の 2 倍とする。

3）加速処理の後には, 必ずその効果を評価する。その ために，各要素は自己に課せられた局所制約条件を用 いる. 加速処理後に，局所制約条件を満たしている場 合は，前ステップにおける加速が有効であると考える ことができ, 次の加速処理における加速量を順次 2,3 , $4 \cdots$ 倍に増加させる。加速処理後に，局所制約条件を 満たさない場合は加速量が過大であると考え，次の加 速量を初期值にもどす。

設計空間における設計点の加速処理による移動は次 のように考えることができる.すなわち，設計点のこ れまでの移動に関する情報からこれれら移動するで あろう方向が予測でき，その方向に大きく設計点を移 動させるものである。

この加速アルゴリズムは, 要素間で情報の交換を行う 必要がない，および各要素は局所的に加速の効果を検 証できるといった特徽を持ち，並列処理に適している といえる.

\subsection{2収束加速アルゴリズムの有効性の検証} DORAR 法に提案した要素の収束加速アルゴリズムを 適用し, 図 2 に示す 5 種類の初期值から最適化を行っ たときの 500 ステップまでの資源履歴を図 13 に示す。 


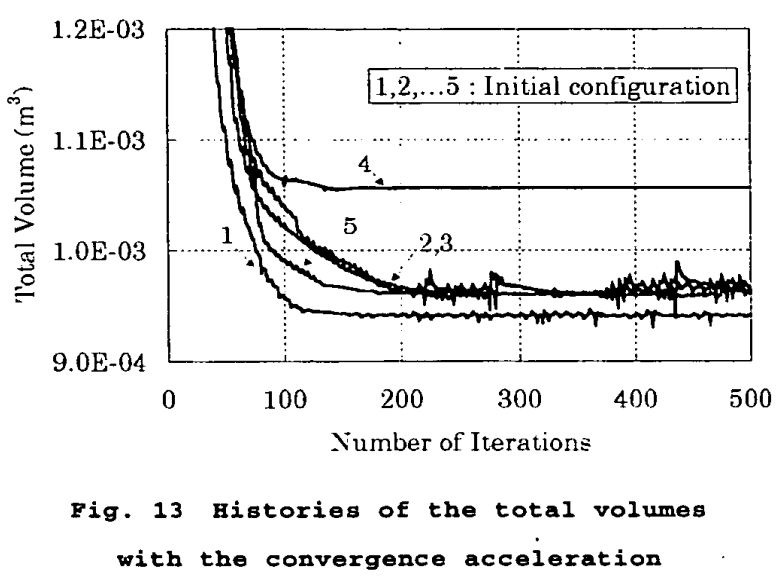

図 9 に示す通常の DORAR法による最適化における資 源の履歴と比較すると, 収束加速アルゴリズムを適用 することで, 5 種類のすべての初期值から収束性の大幅 な向上が実現できることがわかる。また，各要素がシ ステムの状態に応じた加速量を与えるために，分散的 かつ適応的に加速の大きさを決定することは収束の高 速化には有效であると考えられる。

\section{5. 結論}

本研究では, 資源の最適な配分問題に帰着される最適 化問題を並列分散的に解くための新しい方法として前 報で提案されたDORAR 法に収束性の改善および最適

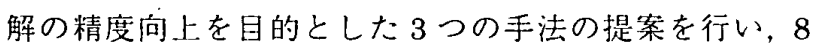
節点 15 部材トラス構造物最小体積設計問題に適用する ことでその有効性を検証した。

得られた結論は以下の通りである。

1）資源追加処理に打いて，各要素に付加する一定の微 少な資源 $\Delta R$ は収束性や最適解の精度に大きな影響を 及ぼすものであることがわかった。すなわち， $\Delta R$ が 大きければ，収束の高速化が実現できるが精度が悪い。 逆に $\Delta R$ が小さけ机ば，最適解の精度向上が実現でき るが収束が荤くなることがわかった。

2）全体の資源量の変化量を基準として，追加資源 $\Delta R$
を段階的に低減することで，収束性の改善および最適 解の精度问上の両者を実現できた。

3）感度情報を用いた責任係数の適応的変化は，必ずし も良好な結果をもたらすものではないことがわかっ た，このため，責任係数を一定と考える従来の考え方 は有効であった。ただしここでの計算例では 100 回 程度の計算の繰返し後から感度情報を用いて幊任係 数を適応的に变化させることで，収束が加速されるこ とがわかった。これは，責任係数の初期解依存性をな くすためである。これより，最初は責任係数を一仯と し，設計解の変化が緩慢となってから責任係数を適応 的に変化させる方法が良いと思われる。

4）離散的な各要素が資源の变化を記憶することで，分 散的かつ適応的に収束加速を行うアルゴリズムを提 案した。各要素が自律分散的な加速を行った結果，シ ステム全体として最適な状態への収束性の问上が笑 現できた。

\section{参考文献}

1) Schnabel,R.B., "A View of the Limitations, Opportunities, and Challenges in Parallel Nonlinear Optimization", Parallel Computing, Vol.21, pp.875-905, 1995

2）霖,宮本,井原，“自律分散概念の提案”，電気学会論 文誌 C, Vol.104 No.12，1987

3）三木光範,廣安知之，“資源の追加と削減に基づく最 適化法”，日本機械学会論文集 A 編, Vol.66 No.642, pp.1-8, 2000

4) M.Miki , "Object-Oriented Optimization of Discrete Structures", AIAA Journal , Vol.33 No.10, pp.1940-1945, 1995

5) M.Miki, T.Hiroyasu, T.Ikeda , "Parallel Distributed Optimization by Resource Addition and Reduction", Lecture Notes in Computer Science 1615,Springer, pp.194-205, 1999 